\title{
Brefeldin A disturbs Golgi complex integrity but does not impair ecdysis in the dinoflagellates Prorocentrum cordatum
}

\author{
Ilya Pozdnyakov, Mariia Berdieva, Vera Kalinina, \\ Sofia Pechkovskaya and Olga Matantseva
}

\author{
Institute of Cytology, Russian Academy of Sciences, Saint Petersburg 194064, Russia
}

| Submitted February 3, 2021 | Accepted March 25, 2021 |

\begin{abstract}
Summary
The marine planktonic dinoflagellate Prorocentrum cordatum (syn. Prorocentrum minimum) is a thecate species capable of ecdysis, i.e. rearrangement of the cell covering in response to different stressors. During the process of ecdysis, $P$. cordatum cells shed the plasma membrane and outer amphiesmal vesicle membrane, and become immotile, covered only by thecal plates and the new plasma membrane. At this stage, the cells can be considered as thecal cysts. Then, they complete ecdysis by leaving the old thecal plates and restoring motility, i.e. excyst. To elucidate the role of vesicular transport in the cell covering rearrangement, we tested the effect of brefeldin A, the inhibitor of vesicular transport from the endoplasmic reticulum to the Golgi complex widely used in cell biology, on the cellular structure of P. cordatum and its ability to ecdyse. We found out that brefeldin A blocked vesicular trafficking from the endoplasmic reticulum to the Golgi complex, since we observed disassembly of the Golgi complex in cells treated by brefeldin A at $0.1 \mu \mathrm{g} / \mathrm{ml}$ for $1 \mathrm{~h}$. Moreover, such a treatment did not increase mortality in $P$. cordatum culture at the time scale of $6 \mathrm{~h}$. Nevertheless, our experiments demonstrated that brefeldin A affected neither shedding of outer membranes nor discarding of thecal plates during the stressorinduced ecdysis. Based on our findings, we conclude that vesicle trafficking from the endoplasmic reticulum to the Golgi complex and further to the plasma membrane is not essential to the process of membrane and theca shedding. However, this route still can be involved in the process of new amphiesma' maturation, which is discussed in this work.
\end{abstract}

Key words: brefeldin A, dinoflagellates, ecdysis, Golgi complex, Prorocentrum cordatum, vesicle trafficking

\section{Introduction}

The Golgi complex is a component of the endomembrane system in the majority of eukaryotic cells. It participates in the processing, sorting, and transportation of synthesized macromolecules, primarily, proteins. The Golgi complex is also involved in lipid transport and biosynthesis of complex polysaccharides. Its organization varies among different groups of eukaryotes. In most mammalian 
cells, the Golgi apparatus is constituted by multiple stacks that are laterally interconnected with tubules (noncompact zone) (Klumperman, 2011). In plants and algae, it can comprise a few to several hundred individual stacks of cisternae per cell which normally are not interconnected with each other or with the endoplasmic reticulum (Satiat-Jeunemaitre et al., 1996). Meanwhile, a number of organisms across the eukaryotic tree are "Golgi-lacking" (Mowbrey and Dacks, 2009). The marine dinoflagellates possess a well-developed endomembrane system - curved cisternae of endoplasmic reticulum and the Golgi complex (Pavelka and Roth, 2010). The latter consists of several stacks of cisternae with numerous vesicles associated with it laterally and at the poles. The stacks are more or less concentrically organized; they form the so-called centrosomal region adjacent to the nucleus. Besides, according to some reports, there are large vesicles surrounded by stacks and small vesicles (Soyer, 1972; Ausseil et al., 2000).

Dinoflagellates possess a special cell covering - amphiesma - consisting of a row of membrane vesicles beneath the plasma membrane. In the socalled armored species, amphiesmal vesicles contain cellulosic thecal plates (Morrill and Loeblich, 1983). In the course of a dinoflagellate cell life cycle, amphiesma can undergo drastic changes, particularly, during cell division and ecdysis (Morrill and Loeblich, 1983, 1984; Morrill, 1984; Pozdnyakov and Skarlato, 2012). Ecdysis is a process of the old amphiesma shedding and subsequent formation of its components de novo. The plasma membrane, outer amphiesmal vesicle membranes, undulipodia, and then thecal plates (if present) are discarded, and the inner amphiesmal vesicle membranes fuse to form a continuous membrane that becomes the new plasma membrane. During the immotile stage, cells are covered by a special envelope (pellicle) or by old thecal plates that are then shedded. Subsequently, new amphiesmal vesicles appear and mature; in armored species, new thecal plates are synthesized (Morrill and Loeblich, 1983; Morrill, 1984; Bricheux et al., 1992; Sekida et al., 2001; Pozdnyakov and Skarlato, 2012; Matantseva et al., 2020). The quiescent cell stage formed in the process of ecdysis is considered as a temporary cyst (Bravo and Figueroa, 2014).

Participation of the endoplasmic reticulum and the Golgi complex in the formation of the new amphiesma seems to be logical taking into account their role in the synthesis of membrane lipids, proteins and polysaccharides (Wetherbee, 1975; Okuda and Sekida, 2007). Nevertheless, it is necessary to clarify whether their functioning is essential for ecdysis of the dinoflagellate cell. To test this assumption, we applied brefeldin A - a widelyused drug affecting the organization and functioning of the Golgi complex and, consequently, blocking the vesicle trafficking. We estimated the effect of this drug on cells of the marine armored dinoflagellates Prorocentrum cordatum. This organism has been shown to ecdyse in response to different stressors (Grzebyk and Berland, 1996; Matantseva et al., 2020). At the immotile stage, it is covered only by thecal plates and the new plasma membrane. Such cells can be considered as thecal cysts (Matantseva et al., 2020). We studied changes in the P. cordatum ultrastructure occurring due to incubation with brefeldin A and the impact of this drug on the level of stressor-induced ecdysis in $P$. cordatum culture.

\section{Material and methods}

\section{Cell culture}

Prorocentrum cordatum strain CCAP1136/16 was grown in the artificial seawater-based $\mathrm{f} / 2$ medium (Guillard and Ryther, 1962) without added silicate adjusted to salinity of 25 psu. Culture stocks were maintained at $18^{\circ} \mathrm{C}$ in the glass flasks under a $12 \mathrm{~h} / 12 \mathrm{~h}$ light/dark photoperiod cycle at $100 \mu \mathrm{mol}$ photons $\mathrm{m}^{-2} \mathrm{~s}^{-1}$.

\section{EXPERIMENTAL PROCEDURES}

For experiments, $P$. cordatum cells were inoculated into Erlenmeyer glass flasks with fresh $\mathrm{f} / 2$ medium at a cell concentration of $40 \times 10^{3}$ cells ml $^{-1}$ and then allowed to grow for four days to reach the exponential growth phase. All experiments were performed on the fourth day.

The cells were incubated with $0.1 \mu \mathrm{g} \mathrm{ml}^{-1}$ brefeldin A (stock solution $50 \mu \mathrm{g} / \mathrm{ml}$ in DMSO) or an equal volume of DMSO for $1 \mathrm{~h}$ under standard culture conditions described above. Ecdysis was induced by centrifugation at $4500 \mathrm{~g}$ for $5 \mathrm{~min}$. Then the cells were resuspended in the culture medium. To avoid adhesion of thecal plates to the plastic, the cells were transferred into the glass tubes. All experiments were performed at least in triplicate.

\section{ANALYTICAL PROCEDURES}

The fraction of cells which discarded old plasma and outer amphiesmal vesicle membranes was 
estimated by staining with the cellulose-specific fluorescent stain Calcofluor White M2R (CFW) (Sigma-Aldrich, St. Louis, MO, USA). The fraction of dead cells was estimated by staining with $0.04 \mu \mathrm{g}$ $\mathrm{ml}^{-1}$ propidium iodide (Sigma-Aldrich, St. Louis, MO, USA). The samples were analyzed using Countess II FL Automated Cell Counter (Thermo Fisher Scientific, Waltham, Massachusetts, USA) equipped with an appropriate light cube (Ex (nm) 531/40, Em (nm) 593/40).

The level of complete ecdysis - the fraction of cells that discarded thecal plates - was estimated according to the protocol described by Matantseva with co-authors (2020). Briefly, the samples were taken at the time points $2 \mathrm{~h}$ and $4 \mathrm{~h}$ after treatment. The cells and empty thecal plates were counted using the Fuchs-Rosenthal counting chamber. The proportion of cells that discarded their old thecal plates $\left(\mathrm{E}_{\text {thecae }}\right)$ were calculated using the formula:

$$
\mathrm{E}_{\text {thecas }}=\frac{\frac{\mathrm{N}_{\text {thecae }}}{2}}{\mathrm{~N}_{\text {cells }}} \times 100 \%
$$

where $\mathrm{N}_{\text {thecae }}-$ number of empty thecal plates, $\mathrm{N}_{\text {cells }}$ - total number of cells.

\section{TRANSMISSION ELECTRON MICROSCOPY}

To detect changes in the organization of the Golgi complex at the ultrastructural level, P. cordatum cells were incubated with $0.1 \mu \mathrm{g} \mathrm{ml}^{-1}$ brefeldin A for $30 \mathrm{~min}$ and $1 \mathrm{~h}$. The non-treated cells were used as a control. The cells were fixed in $2.5 \%(\mathrm{v} / \mathrm{v})$ glutaraldehyde (Sigma-Aldrich, USA) at $4{ }^{\circ} \mathrm{C}$ for $40 \mathrm{~min}$, then rinsed and postfixed in $1 \%(\mathrm{w} / \mathrm{v})$ osmium tetraoxide (Sigma-Aldrich, USA) at room temperature for $1 \mathrm{~h}$. After rinsing the pellets were embedded in $2 \%$ agar, dehydrated through a graded series of ethanol, infiltrated with acetone-resin mixtures, and embedded in Epon 812 - Araldite M (Fluka, Switzerland) resin mixture. Ultrathin sections were cut using an Ultracut E (Reichert Jung, Austria) ultramicrotome, contrasted with uranyl acetate and lead citrate, and examined in a Libra 120 (Carl Zeiss, Germany) electron microscope. To assess the state of the Golgi complex in the cells, we studied micrographs obtained from several ultrathin sections for each cell (only the cells for which a series of sections through their central part had been obtained were considered). For each sample, at least 25 P. cordatum cells were investigated.

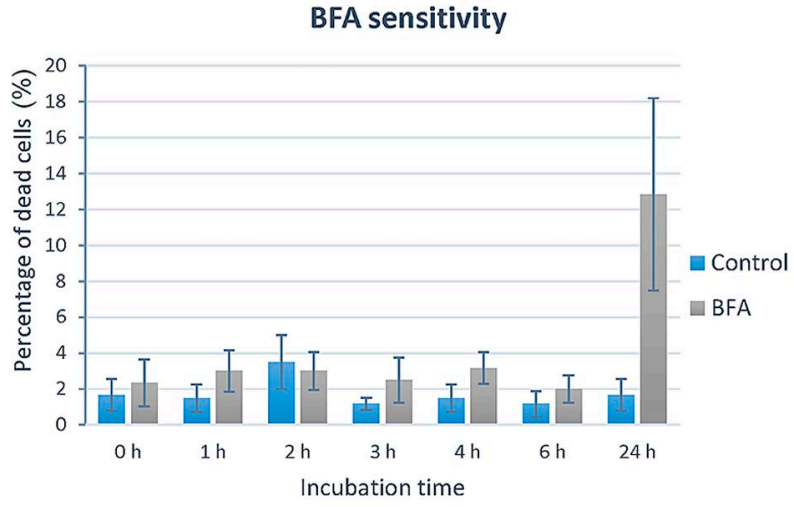

Fig. 1. The fraction of dead P. cordatum cells after incubation with brefeldin $\mathrm{A}$ at a concentration of $0.1 \mu \mathrm{g} \mathrm{ml}^{-1}$ for $0-24 \mathrm{~h}$ and in control (DMSOtreated) samples. The percentage of cells stained with propidium iodide is shown. Hereinafter, mean values are presented, error bars represent the standard error of the mean values.

\section{Results}

Brefeldin A at a concentration of $0.1 \mu \mathrm{g} \mathrm{ml}^{-1}$ had no significant impact on the cell viability during the six-hour incubation as compared to the control samples (Fig. 1). The fraction of dead cells did not exceed $3.2 \% \pm 0.9 \%$ in treated samples $(3.5 \% \pm 1.5 \%$ - in control ones). Only after 24 -h incubation the mortality rate increased to $12.8 \% \pm 5.4 \%$ in the drugtreated cultures, whereas in the control cultures treated by DMSO it did not change (Fig. 1).

We observed changes in the ultrastructure of $P$. cordatum cells after the treatment with brefeldin A. In native state, the Golgi complex consisted of several stacks of cisternae, or dictyosomes, and associated vesicles that concentrated near the nucleus and bounded the so-called centrosomal region (Fig. $2 \mathrm{~A}, \mathrm{~B}$ ). In micrographs, the cisternae were oriented flat (Fig. 2 A) or as a semicircle (Fig. $2 \mathrm{~B})$. The large vesicles with membrane content appeared to be associated with dictyosomes. After 30 min incubation with brefeldin A, most of the studied dinoflagellate cells still contained well-formed dictyosomes (Fig. $3 \mathrm{~A}, \mathrm{~A}^{\prime}$ ), although they were disassembled in some cells (Fig. 3 B, B'). After $1 \mathrm{~h}$ incubation with the drug, we did not reveal organized large dictyosomes in P. cordatum cells, only small residual stacks of flattened vesicles could be detected in some micrographs (Fig. $3 \mathrm{C}, \mathrm{C}^{\prime}$ ).

Nevertheless, $1 \mathrm{~h}$ incubation with brefeldin A did not impede ecdysis induced by centrifugation in 

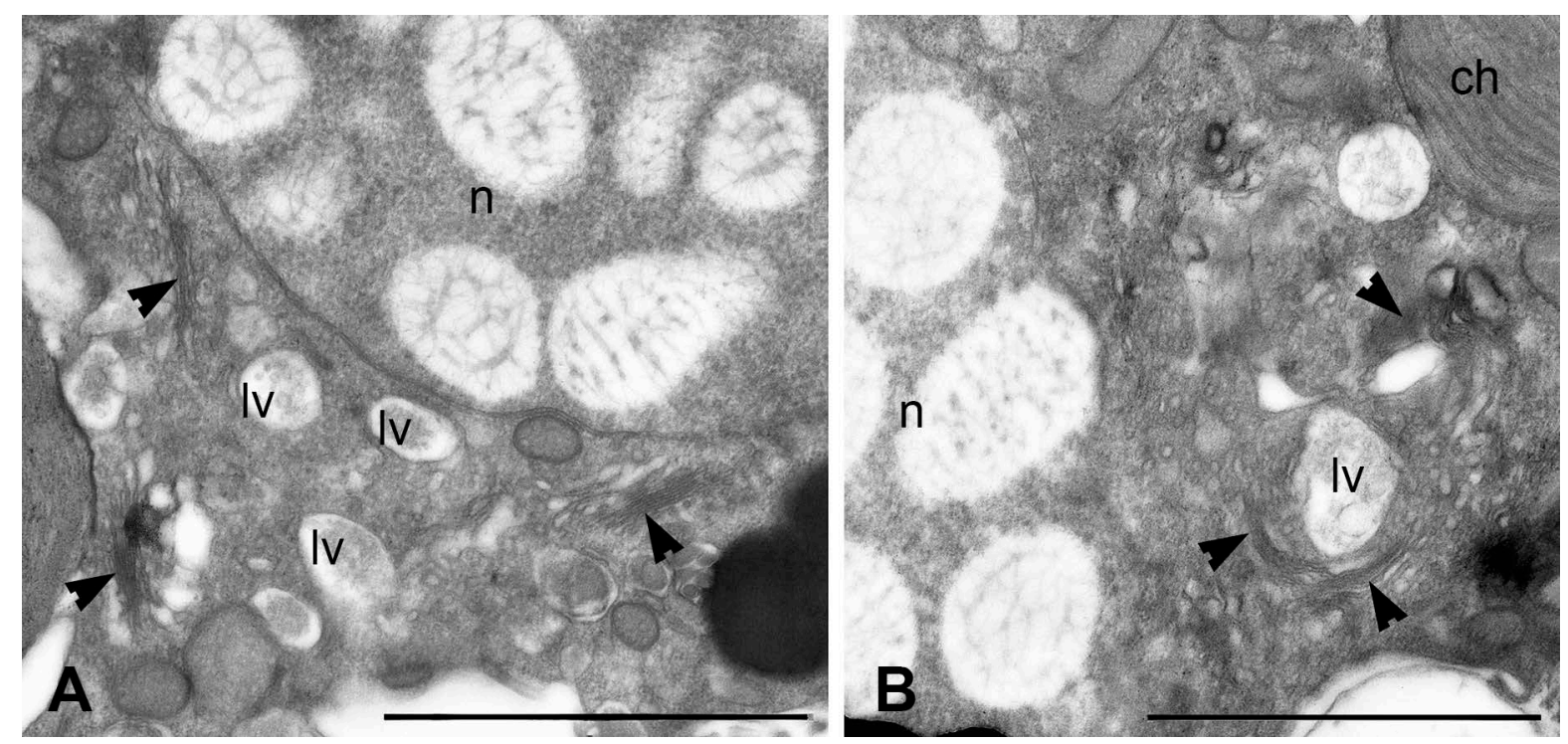

Fig. 2. The ultrastructure of non-treated $P$. cordatum cells, the Golgi complex consists of several well-organized stacks of cisternae (arrowheads) and associated vesicles that concentrated near the nucleus. Abbreviations: ch - chloroplasts, lv - large vesicles, $\mathrm{n}$ - nucleus. Scale bars: $2 \mu \mathrm{m}$.

P. cordatum cells. Over $90 \%$ of dinoflagellate cells in the drug-treated and control samples were stained by CFW immediately after centrifugation, that is, had shedded their outer membranes (Fig. 4). Moreover, the level of the complete ecdysis (shedding of thecal plates) did not change after incubation with brefeldin $\mathrm{A}$ : in $2 \mathrm{~h}$ after centrifugation, $\mathrm{E}_{\text {thecae }}$ reached about $16 \%$, in $4 \mathrm{~h}$ after the centrifugation - about $44 \%$ (Fig. 5).

\section{Discussion}

Here we showed that brefeldin A has an impact on the organization of the Golgi complex in the cells of armored dinoflagellate Prorocentrum cordatum. However, treatment with this drug does not block ecdysis in this organism neither at the stage of discarding plasma membrane and outer amphiesmal membranes nor at the shedding of old thecal plates.

Brefeldin A is a macrocyclic lactone isolated from a variety of fungi (Härri et al., 1963). The treatment with this drug disassembles reversibly the Golgi complex and inhibits the protein secretion in cells of different organisms (Fujiwara et al., 1988; Lippincott-Schwartz et al., 1989; Mérigout et al., 2002; So et al., 2006). In mammalian and yeast cells, brefeldin A has been demonstrated to inhibit the function of GBF1 (yeast homolog Gealp) - specific guanine nucleotide exchange factor associated with membranes of the Golgi apparatus (Niu et al., 2005). GBF1 activates Arf (ADP ribosylation factor) GTPase that provides recruitment of coat proteins participating both in retro- and anterograde pathway and lipid-modifying enzymes essential for the protein sorting and membrane deformation events associated with vesicle trafficking (SatiatJeunemaitre et al., 1996; Niu et al., 2005). Brefeldin A stabilizes GBF1 on Golgi membranes (Niu et al., 2005).

Brefeldin A induces disassembling of the Golgi complex in a different manner in different organisms and cell types. There can be complete vesiculation and disappearance of the stacks or only a partial unstacking (Satiat-Jeunemaitre et al., 1996). In plant cells, stacks can aggregate to form the so-called brefeldin A- (BFA-) compartments (Satiat-Jeunemaitre et al., 1996). The trans-Golgi can be the first to be disrupted by this drug in some plant cell types (Satiat-Jeunemaitre et al., 1996); in mammalian cells, cis-Golgi is the first to undergo transformation (Lippincott-Schwartz et al., 1989).

In dinoflagellates, disappearance of the Golgi complex has been observed in response to incubation of Gonyaulax (=Lingulodinium) polyedra cells with $0.3 \mu \mathrm{g} \mathrm{ml} \mathrm{m}^{-1}$ brefeldin A (Nassoury et al., 2005). Authors described an unusual inclusion body (BFAbody) located in the central region adjacent to the nucleus that contained electron-dense and electronlucent regions (Nassoury et al., 2005). In this orga- 

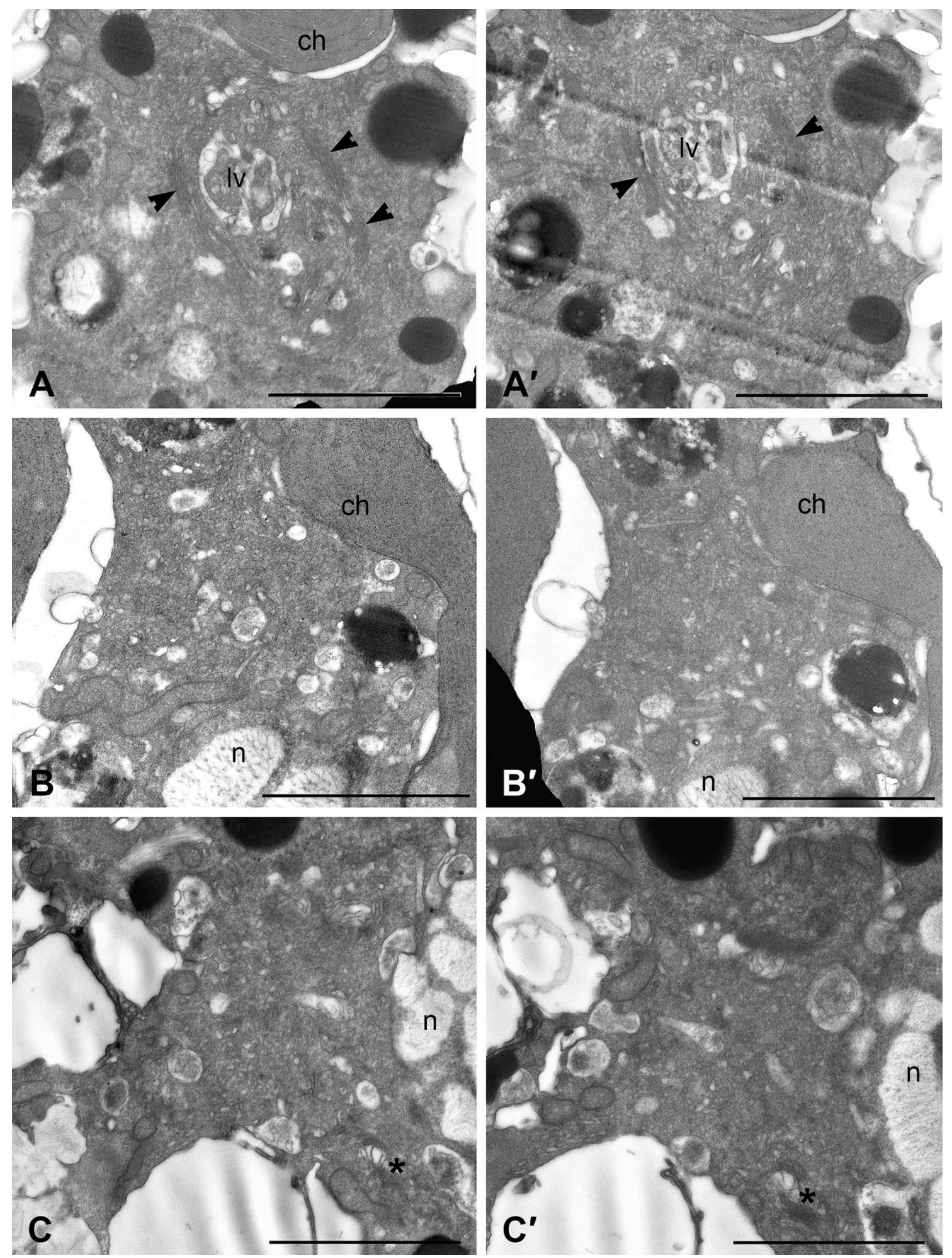

Fig. 3. The ultrastructural changes in $P$. cordatum cells after incubation with brefeldin $\mathrm{A}$ at a concentration of $0.1 \mu \mathrm{g} \mathrm{ml} l^{-1}$. A-B - Cells after 30-min incubation with brefeldin $\mathrm{A} ; \mathrm{A}, \mathrm{A}^{\prime}-$ cell, which retains organization of the Golgi complex (stacks are marked by arrowheads); B, B' - cell with disassembled dictyosomes; C, $\mathrm{C}^{\prime}-$ cells after 1-h incubation with brefeldin A, vesiculation of dictyosomes occurs, residual stacks can be observed (asterisks). Abbreviations: $\mathrm{ch}$ - chloroplasts, lv - large vesicles, $\mathrm{n}$ - nucleus. Scale bars: $2 \mu \mathrm{m}$. 


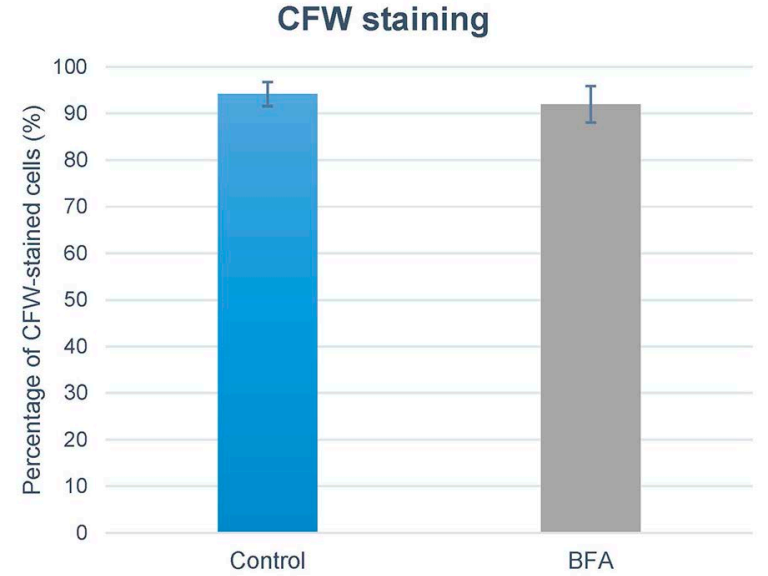

Fig. 4. The fraction of $P$. cordatum cells which entered ecdysis, i.e. discarded plasma membrane and outer membranes of amphiesmal vesicles in samples incubated with brefeldin A and in control ones. The percentage of cells stained with Calcofluor White M2R is shown.

nism, brefeldin A $\left(0.1\right.$ or $\left.0.3 \mu \mathrm{g} \mathrm{ml}^{-1}\right)$ inhibited mobilization of newly synthesized enzyme Rubisco from the plastid periphery to pyrenoids (Nassoury et al., 2005). According to our observations, almost complete vesiculation of the dictyosomes of $P$. cordatum occurs in response to 1-h incubation with brefeldin A.

The actual mechanisms and regulation of ecdysis remain unclear. In particular, what factors trigger the discarding of outer membranes and thecal plates, and what molecular rearrangements are required for the completion of this process? In this work, we focused on the potential role of vesicular trafficking for the process of ecdysis. Vesicular trafficking from the endoplasmic reticulum to the Golgi complex and further to the plasma membrane is necessary for the growth of the plasma membrane and the adjustment of its lipid and protein content. Moreover, it is likely to be involved in the growth and maturation of the amphiesmal vesicles. These processes may be prerequisites of the ecdysis process completion. In addition, the active growth of the plasma membrane may represent the mechanism underlying the cell release from old thecal plates. In this work we focused on testing the hypothesis about the importance of the endoplasmic reticulum-Golgi complex-plasma membrane vesicular trafficking route for successful ecdysis.

Synthesis of new plasma membrane lipids and proteins occurs in the endoplasmic reticulum

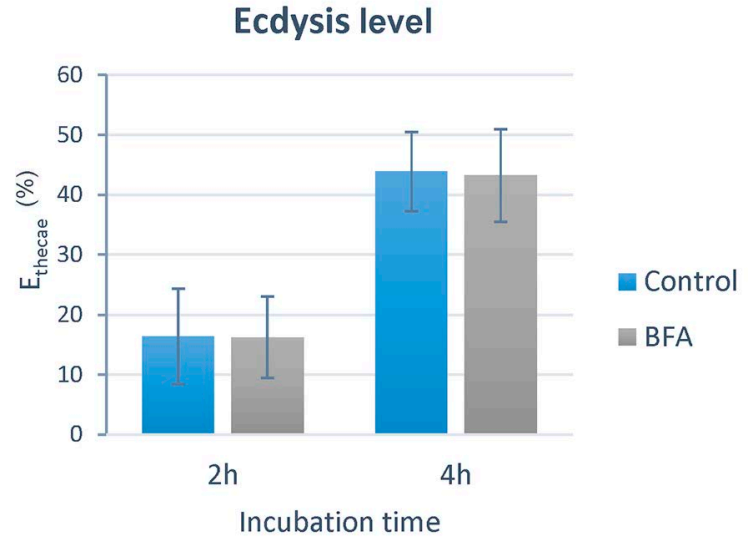

Fig. 5. Effect of brefeldin A on the level of complete ecdysis, i.e. theca shedding, $\left(\mathrm{E}_{\text {thecae }}\right)$ induced by centrifugation in $P$. cordatum culture. The percentage of cells which shedded the old thecal plates is shown.

(Yeagle, 2016). The Golgi apparatus also takes a part in the synthesis and maturation of lipids and proteins of membranes and, as an important station of the anterograde pathway, in their transportation to the plasma membrane. Thus, disturbance of the Golgi complex organization should block the flow of new components to the membrane. The effect of brefeldin A on the access of newly synthesized phospholipids, for instance, sphingomyelin, to the plasma membrane surface in vertebrate cells has been confirmed in some earlier studies (Kallen et al., 1993).

Intriguingly, brefeldin A added in the culture medium did not impede both steps of ecdysis in $P$. cordatum cells. Therefore, transportation of membrane components to the cell surface in itself appears to be not necessary for ecdysis. It should be also noted that the effect of this drug is reversible, and the endomembrane system can be restored even in the presence of brefeldin (Fujiwara et al., 1988). However, in our experiments cell mortality rate increased in the brefeldin A-treated culture after 24-h incubation indicating that this compound still had an effect on the cells.

Besides, in the experimental study of mammalian hepatocytes, it has been shown that brefeldin A did not inhibit movement of phosphatidylethanolamine - one of the membrane phospholipids - from synthesis sites to the plasma membrane (Vance et al., 1991). In fibroblasts transfected with VSVG- 
GFP, it was demonstrated that transport of VSVGloaded carriers is not sensitive to brefeldin A, despite the Golgi disassembly (Patterson et al, 2008). The Golgi export domains appear to be resistant to drug treatment and do not return to the endoplasmic reticulum (Patterson et al, 2008). In protistan cells, there are alternative routes of secretion, e.g., endosomal-lysosomal trafficking in Giardia cells (Touz et al., 2012). It cannot be excluded that dinoflagellate cells can overcome the absence of the endoplasmic reticulum-Golgi complex transport by using other trafficking routs for the necessary amphiesma components. Particularly, large vesicles that are presented in both brefeldin-treated and control cells could be involved in the process of secretion. Besides, the role of large cortical vesicles located beneath the amphiesma, which had been described earlier, remains unclear (Matantseva et al., 2020).

Nevertheless, we may assume that impact of brefeldin A on P. cordatum cells is more likely to be expressed in inhibition of maturation of the new amphiesma. The Golgi complex is a site of synthesis of polysaccharides for the cell wall, at least in plant cells (Satiat-Jeunemaitre et al., 1996). The vesicles that are believed to originate from the Golgi apparatus are considered carriers of cellulose precursors for the formation of new thecal plates in dinoflagellate cells (Wetherbee, 1975; Okuda and Sekida, 2007). The effect of brefeldin A on the biosynthesis of cell wall polysaccharides has been shown in plant root cells and red algae (SatiatJeunemaitre et al., 1996; Lanubile et al., 1997). Thus, $P$. cordatum cells that have left old thecal plates are most likely to have immature amphiesma. The testing of this hypothesis should be an agenda for the immediate future researches.

\section{Acknowledgments}

The research was funded by the Russian Science Foundation, project No 18-74-10093.

\section{References}

Ausseil J., Soyer-Gobillard M.-O., Géraud M.-L., Bhaud Y., Perret E., Barbier M., Albert M., Plaisance L. and Moreau H. 2000. Dinoflagellate centrosome: associated proteins old and new. Eur. J. Protistol. 36, 1-19.
Bravo I. and Figueroa R. 2014. Towards an ecological understanding of dinoflagellate cyst functions. Microorganisms. 2, 11-32.

Bricheux G., Mahoney D.G. and Gibbs S.P. 1992. Development of the pellicle and thecal plates following ecdysis in the dinoflagellate Glenodinium foliaceum. Protoplasma. 168, 159-171.

Fujiwara T., Oda K., Yokota S., Takatsuki A. and Ikehara Y. 1988. Brefeldin A causes disassembly of the Golgi complex and accumulation of secretory proteins in the endoplasmic reticulum. J. Biol. Chem. 263, 18545-52.

Grzebyk D. and Berland B. 1996. Influences of temperature, salinity and irradiance on growth of Prorocentrum minimum (Dinophyceae) from the Mediterranean Sea. J. Plankton Res. 18, 18371849.

Guillard R.R.L. and Ryther J.H. 1962. Studies of marine planktonic diatoms: I. Cyclotella nana Hustedt, and Detonula confervacea (Cleve) Gran. Can. J. Microbiol. 8, 229-239.

Härri E., Loeffler W., Sigg H.P., Stähelin H. and Tamm C. 1963. Über die Isolierung neuer Stoffwechselprodukte aus Penicillium brefeldianum Dodge. Helvetica. 46, 1235-1243.

Kallen K.J., Quinn P. and Allan D. 1993. Effects of brefeldin A on sphingomyelin transport and lipid synthesis in BHK21 cells. Biochem. J. 289, 307-312.

Klumperman J. 2011. Architecture of the mammalian Golgi. Cold Spring Harb. Perspect. Biol. 3, a005181-a005181.

Lanubile R., Piro G. and Dalessandro G. 1997. Effect of Brefeldin A on the synthesis and transport of cell wall polysaccharides and proteins in pea root seedlings. J. Exp. Bot. 48, 1925-1933.

Lippincott-Schwartz J., Yuan L.C., Bonifacino J.S. and Klausner R.D. 1989. Rapid redistribution of Golgi proteins into the ER in cells treated with brefeldin A: Evidence for membrane cycling from Golgi to ER. Cell. 56, 801-813.

Matantseva O., Berdieva M., Kalinina V., Pozdnyakov I., Pechkovskaya S. and Skarlato S. 2020. Stressor-induced ecdysis and thecate cyst formation in the armoured dinoflagellates Prorocentrum cordatum. Sci. Rep. 10, 18322.

Mérigout P., Кépиs F., Perret A.-M., SatiatJeunemaitre B. and Moreau P. 2002. Effects of brefeldin A and nordihydroguaiaretic acid on endomembrane dynamics and lipid synthesis in plant cells. FEBS Lett. 518, 88-92.

Morrill L.C. 1984. Ecdysis and the location of 
the plasma membrane in the dinoflagellate Heterocapsa niei. Protoplasma. 119, 8-20.

Morrill L.C. and Loeblich A.R. 1983. Ultrastructure of the dinoflagellate amphiesma. Int. Rev. Cytol. 82, 151-180.

Morrill L.C. and Loeblich A.R. 1984. Cell division and reformation of the amphiesma in the pelliculate dinoflagellate, Heterocapsa niei. J. Mar. Biol. Assoc. United Kingdom 64, 939-953.

Mowbrey K. and Dacks J.B., 2009. Evolution and diversity of the Golgi body. FEBS Lett. 583, 3738-3745.

Nassoury N., Wang Y. and Morse D. 2005. Brefeldin A inhibits circadian remodeling of chloroplast structure in the dinoflagellate Gonyaulax. Traffic. 6, 548-561.

Niu T.-K., Pfeifer A.C., Lippincott-Schwartz J. and Jackson C.L. 2005. Dynamics of GBF1, a brefeldin A-sensitive Arf1 exchange factor at the Golgi. Mol. Biol. Cell. 16, 1213-1222.

Okuda K. and Sekida S. 2007. Cellulosesynthesizing complexes of a dinoflagellate and other unique algae. In: Cellulose: Molecular and Structural Biology (Eds: Brown R.M. Jr. and Saxena I.M.). Springer Netherlands, Dordrecht, pp. 199-215.

Pavelka M. and Roth J. 2010. Endomembrane System of Dinoflagellates. In: Functional ultrastructure (Eds: Pavelka M. and Roth J.). Springer Vienna, Vienna, pp. 26-27.

Patterson G.H., Hirschberg K., Polishchuk R.S., Gerlich D., Phair R.D. and LippincottSchwartz J. 2008. Transport through the Golgi apparatus by rapid partitioning within a two-phase membrane system. Cell. 133, 1055-1067.
Pozdnyakov I. and Skarlato S. 2012. Dinoflagellate amphiesma at different stages of the life cycle. Protistology. 7, 108-115.

Satiat-Jeunemaitre B., Cole L., Bourett T., Howard R. and Hawes C. 1996. Brefeldin A effects in plant and fungal cells: something new about vesicle trafficking? J. Microsc. 181, 162-177.

Sekida S., Horiguchi T. and Okuda K. 2001. Development of the cell covering in the dinoflagellate Scrippsiella hexapraecingula (Peridiniales, Dinophyceae). Phycol. Res. 49, 163-176.

So D.Y.F., Temkin R.J. and Lea P.J. 2006. Effects of brefeldin-A on Golgi morphology in human cultured fibroblasts observed in threedimensional stereo scanning electron microscopy. Scanning. 17, 161-170.

Soyer M.O. 1972. Les ultrastructures nucleaires de la Noctiluque (Dinoflagelle libre) au cours de la sporogenese. Chromosoma. 39, 419-441.

Touz M.C., Rivero M.R., Miras S.L. and Bonifacino, J.S. 2012. Lysosomal protein trafficking in Giardia lamblia: common and distinct features. Front. Biosci. (Elite edition). 4, 1898-1909.

Vance J.E., Aasman E.J. and Szarka R. 1991. Brefeldin A does not inhibit the movement of phosphatidylethanolamine from its sites for synthesis to the cell surface. J. Biol. Chem. 266, 8241-8247.

Wetherbee R. 1975. The fine structure of Ceratium tripos, a marine armored dinoflagellate. III. Thecal plate formation. J. Ultrasructure Res. 50, 77-88.

Yeagle P.L. 2016. Membrane Biogenesis. In: The Membranes of Cells (Ed: Yeagle P.L.). Academic Press, pp. 269-290.

Address for correspondence: Olga Matantseva. Institute of Cytology of the Russian Academy of Sciences, Laboratory of Cytology of Unicellular Organisms, Tikhoretsky Ave. 4, 194064 St. Petersburg, Russia; e-mail: matantseva@incras.ru 